\title{
Breast- $v$. formula-feeding: impacts on the digestive tract and immediate and long-term health effects
}

\author{
Isabelle Le Huërou-Luron ${ }^{1,2} *$, Sophie Blat ${ }^{1,2}$ and Gaëlle Boudry ${ }^{1,2}$ \\ ${ }^{1}$ INRA, UMR 1079, SENAH, F-35590 Saint-Gilles, France \\ ${ }^{2}$ Agrocampus Ouest, UMR 1079, SENAH, F-35000 Rennes, France
}

\begin{abstract}
The health benefits of breast-feeding have been recognised for a long time. In particular, breast-feeding is associated with lower incidence of necrotising enterocolitis and diarrhoea during the early period of life and with lower incidence of inflammatory bowel diseases, type 2 diabetes and obesity later in life. The higher nutritional and protective degree of human milk is related to its nutritional composition that changes over the lactation period and to the biological activities of specific components while lower growth rate of breast-fed infants may be attributed to their self-regulation of milk intake at a lower level than formula-fed infants. Many results now suggest that the developmental changes in intestinal and pancreatic function that occur postnatally are modulated by the diet. Indeed, formula-feeding induces intestinal hypertrophy and accelerates maturation of hydrolysis capacities; it increases intestinal permeability and bacterial translocation, but does not induce evident differences in microbiota composition. Whether these changes would be beneficial for enhancing absorptive capacities and for educating the gut-associated immune system remains to be further studied. Moreover, it is evident that formula-feeding increases basal blood glucose and decreases plasma ketone body concentrations, while discrepancies on postprandial glycaemia, insulin and incretin responses in both human studies and experimental studies are inconclusive. Manipulating the composition of formula, by reducing protein content, adding prebiotics, growth factors or secretory $\operatorname{IgA}$ can modulate intestinal and pancreatic function development, and thereby may reduce the differential responses between breast-fed and formula-fed neonates. However, the developmental responses of the digestive tract to different feeding strategies must be elucidated in terms of sensitivity to developing diseases, taking into account the major role of the intestinal microbiota.
\end{abstract}

Human milk: Formula: Early nutrition: Gastrointestinal tract development: Endocrine pancreas: Intestine

The intestine as the first barrier for nutrients and luminal components and the endocrine pancreas for its major role in glycidic homeostasis have a central role in determining postnatal defence and metabolic programming. At birth the gastrointestinal tract and the pancreas are immature and their development continues during the first years of life. Although mainly genetically programmed, these developmental changes can be modulated by the diet. Breast-feeding is the best protection for infants after birth and as such reduces the risk of diseases during the milk period. It is also associated with long-term health benefits. Compared with formula, human milk is very complex, providing both an optimal nutrition for the newborn and components with biological activities that drive the growth of the intestine and pancreas and contribute to the development of mucosal defences.
The objective of the present review is to compare the effect of breast- $v$. formula-feeding on the postnatal development of the gastrointestinal tract and the endocrine pancreas and discuss the possible consequences of these differences later in life (Fig. 1). The prevalence of breastfeeding and the associated short- and long-term health benefits, as well as the dynamic changes in human milk composition are considered first. Differences in the pattern of intestinal and pancreatic development during the early postnatal period in breast-fed $v$. formula-fed neonates are then reviewed. Finally, evidence is given to support the fact that modifying the nutritional content or adding human milk-like components to formula may be favourable for the intestinal and pancreatic developmental patterns. The focus is principally on intestinal and pancreatic development in

\footnotetext{
Abbreviations: EGF, epidermal growth factor; GIP, glucose-dependent insulinotropic peptide; GLP, glucagon-like peptide; IGF-I, insulin-like growth factor-I.

* Corresponding author: Dr Isabelle Le Huërou-Luron, fax +33 223485080, email Isabelle.Luron@ rennes.inra.fr
} 


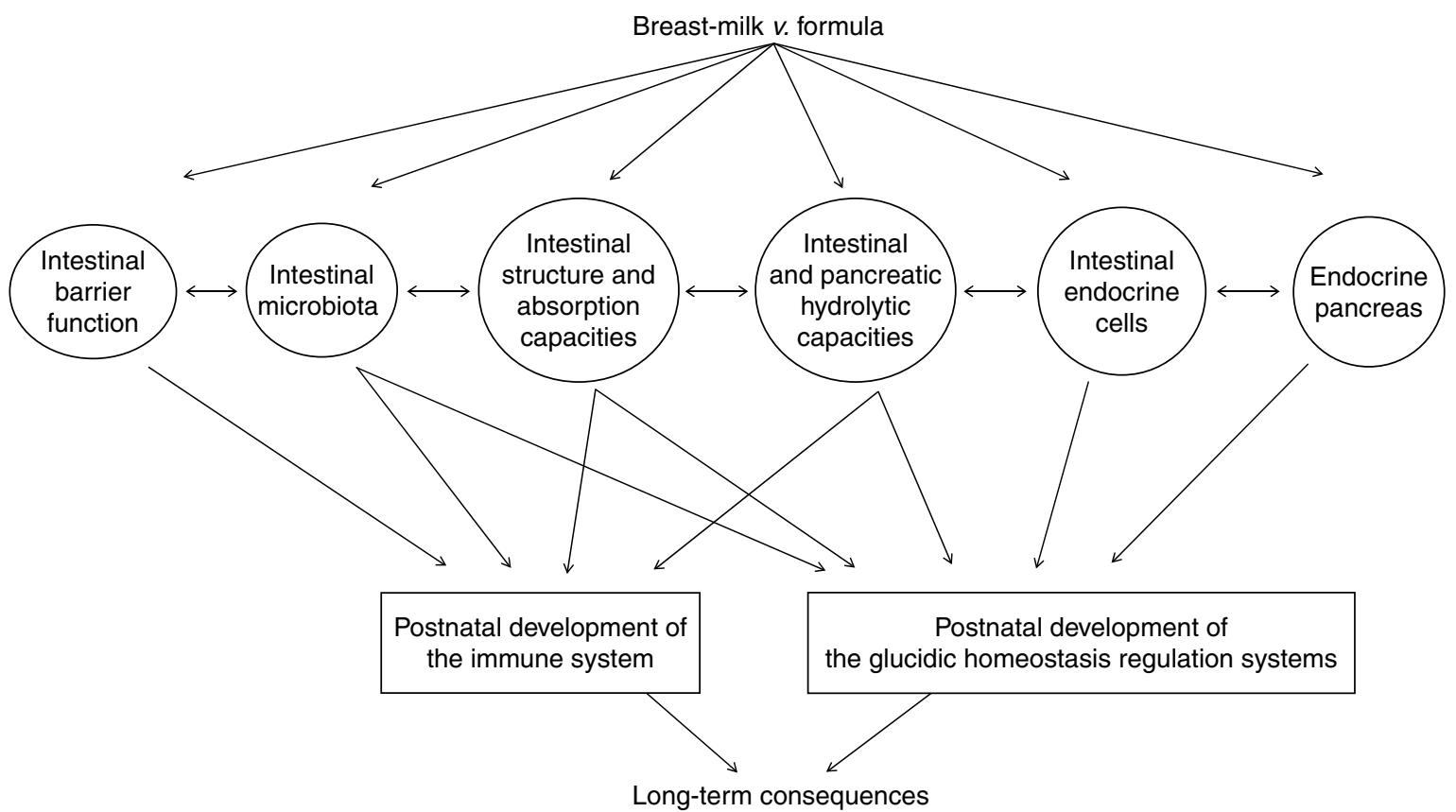

Fig. 1. Intestinal and pancreatic functions that can be modulated by formula- $v$. breast-feeding and have long-term consequences.

humans. However, the effect of nutrition on the postnatal gastrointestinal tract and pancreas growth and development is poorly defined in humans, mostly because of ethical difficulties in conducting nutritional intervention studies and obtaining tissue from healthy infants. Therefore, results from in vitro or experimental animal studies have been included.

\section{Breast-feeding $\boldsymbol{v}$. formula-feeding prevalence}

The WHO recommends exclusive breast-feeding for 6 months, and supplemental breast-feeding up to 2 years and beyond. Between 1990 and 2000-4, the global worldwide prevalence of exclusive breast-feeding for the first 4 months of life has increased up to $41 \%$ and to $25 \%$ for the first 6 months of life ${ }^{(1)}$. However, a large disparity appears between regions due to social, economic, ethnic and hygiene factors and some uncertain circumstances. The prevalence of breast-feeding early postpartum is above $90 \%$ in most countries (except in Belgium, Canada, France, North Ireland, The Netherlands, UK and USA where it ranges between 50 and $75 \%$ ) while the percentages for 4-6 months exclusive breast-feeding are well below (Table 1). In 2000, the prevalence of exclusive breast-feeding until age 4 months was on average $30 \%$ in Africa, the USA and Canada, and more than $60 \%$ in Asia, the Pacific and Scandinavia. However, it was only $7 \%$ in the UK and less than $5 \%$ in France in 2005. In fact, the average duration of breast-feeding is 10 weeks in France and half the women who start breast-feeding stop by 2 months in the UK. Despite numerous initiatives to promote breast-feeding, some countries seem to be more resistant to change ${ }^{(2)}$. These data clearly emphasise that many infants are still formulafed for periods of their first months of life. Improvement of the nutritional and non-nutritional quality of formula must therefore remain an area of research to improve formula-fed infant nutrition and health.

\section{Short- and long-term child health benefits associated with breast-feeding}

Short- and long-term child health benefits associated with breast-feeding have been widely reported ${ }^{(3)}$ and concerns several organs and tissues ${ }^{(2)}$. Benefits are largely dependent on the duration of breast-feeding and on the age of introduction of complementary foods. When focusing on the

Table 1. Prevalence (\%) of exclusive breast-feeding in the world in $2000-5^{*}$

\begin{tabular}{lcc}
\hline & Early postpartum & At age $4-6$ months \\
\hline Worldwide & 90 & 41 \\
Africa & $>92 \dagger$ & 30 \\
America & 72 & \\
$\quad$ Canada & 70 & 30 \\
USA & $>92$ & 30 \\
Latin America & $>93 \ddagger$ & $2-77$ \\
East and South Asia & & 60 \\
Europe & & \\
Belgium & $50-75$ & nd \\
France & & 5 \\
Northern Ireland & & nd \\
The Netherlands & 99 & 7 \\
UK & 97 & 65 \\
Norway & $>87$ & 65 \\
Sweden & & 60 \\
The Pacific & &
\end{tabular}

nd, No available data. ${ }^{*}$ Adapted from Hoddinott et al. ${ }^{(2)}$, La Leche League International ${ }^{(105)}$, Forste \& Hoffmann ${ }^{(106)}$ and Turck ${ }^{(107)}$ '.

† Except Mauritania (72\%).

$\ddagger$ Except Philippines (88\%). 
digestive tract, short-term benefits includes reduced risks of infectious diarrhoea and necrotising enterocolitis ${ }^{(4)}$. Diarrhoea was reported to be reduced by half in breast-fed $v$. formula-fed infants during the period of breast-feeding $(2,5)$ or even beyond ${ }^{(6)}$. Food allergies have also been reported to be less frequent in breast-fed infants ${ }^{(7)}$ although other studies have failed to detect such associations ${ }^{(8)}$. Breastfeeding has also been associated with a reduced risk of type 1 diabetes in infancy ${ }^{(9)}$, while early introduction of cows' milk has been associated with increased risk through stimulation of the autoimmune process ${ }^{(10)}$. However, in a recent extended secondary analysis of a population-based cohort, very early exposure to cows' milk was demonstrated not to be a risk factor for type 1 diabetes and even to diminish its appearance before 8 years of age $e^{(8)}$. In the same study, no association between breast-feeding duration and the appearance of type 1 diabetes could be found ${ }^{(8)}$.

Long-term consequences of breast-feeding on health have also gained an increasing attention during recent decades. Breast-feeding may confer protection against diseases such as inflammatory bowel disease and type 2 diabetes, as well as against obesity. The role of breast-feeding in the development of paediatric inflammatory bowel disease was the object of a recent meta-analysis ${ }^{(11)}$. Breast milk exposure had a significant protective effect on the development of early-onset inflammatory bowel disease, although the authors highlighted the poor quality of existing data and the need to perform well-designed prospective studies. Moreover, it has been specifically demonstrated that in a population with a high prevalence of type 2 diabetes, the Pima Indians, people who had been exclusively breast-fed had significantly lower rates of type 2 diabetes than those who had been exclusively formula-fed ${ }^{(12)}$. A recent analysis of published studies acknowledged that breast-feeding in infancy was associated with a reduced risk of type 2 diabetes, with marginally lower insulin concentrations later in life, and lower blood glucose and serum insulin concentrations in infancy ${ }^{(13)}$. A recent report of the WHO underscores the fact that although the beneficial effects of breast-feeding were statistically significant, their magnitude may be relatively modest for some health outcomes ${ }^{(3)}$. The beneficial effect of breast-feeding was smaller for the prevention of type 2 diabetes than those derived from other public health interventions such as dietary advice and physical activity. Breast-feeding was associated with a $22 \%$ reduction in the prevalence of overweight/obesity ${ }^{(3)}$ while the effectiveness of dietary education and physical activity is still debated ${ }^{(14)}$. Therefore the epidemiological data clearly highlight the importance of breast-feeding and its consequences on the susceptibility to later developing diseases.

\section{Human milk composition}

There may be several reasons for differences in the health of breast-fed and formula-fed infants. The complex composition of human milk and its dynamic changes over the lactation period are likely to play a major role. In addition to nutrients, human milk also contains hormones, growth factors, immunoglobulins, cytokines, enzymes, etc that support both the growth and the passive defences of the infant.
Human milk composition is influenced by gestational age at parturition and postnatal age and it can actively accelerate the development of the infant's own defences ${ }^{(15)}$.

The protein content of human milk decreases rapidly during the first month of lactation (14-16 g/l during early lactation, $8-10 \mathrm{~g} / 1$ at $3-4$ months and $7-8 \mathrm{~g} / 1$ at 6 months and later). This decrease is mainly due to the diminution in whey protein concentration ${ }^{(16)}$. The ratio of whey:casein changes from 80:20 during the first days of lactation to 60:40 at 2-3 months of lactation. As a consequence, the amino acid content of human milk also varies during the early phase of lactation. The concentration of lipids and lactose is low in the very early milk, which results in a lower energy content of breast milk during early lactation. Thereafter, the fat content of human milk is on average $35 \mathrm{~g} / \mathrm{l}$. It is noticeable that although always present, the concentration of PUFA varies widely between women, reflecting the composition of fat in the mother's diet ${ }^{(17)}$. Carbohydrates (about $75 \mathrm{~g} / \mathrm{l}$ ) are mainly provided by lactose $(85 \%)$ and complex oligosaccharides.

Human milk also contains a wide variety of proteins that display multiple biological activities: modulation of digestion and utilisation of macro- and micronutrients; immunomodulatory activities; trophic effects on intestinal mucosa; hormonal activities (Table 2). Proteins of human milk are specific and quite different from bovine proteins, and there is a wide variety of unique proteins in human milk with particular biological activities (Table 2). The protein composition of formula reflects more that of mature human milk, without taking into account the gradually changing pattern of human milk protein content along the breastfeeding period, although this goal seems now to be technically and nutritionally conceivable ${ }^{(18)}$. Considering fat, carbohydrate, mineral and vitamin contents, formula diets are similar to mature human milk, though some components (sphingomyelin, specific oligosaccharides, etc) are still lacking.

\section{Breast- $v$. formula-feeding: impact on infant growth rate}

Exclusive breast-feeding during the first 6 months fulfils the needs of tissues and organs during this period and allows normal growth. The growth rate of infants breast-fed for more than 12 months decelerates more rapidly compared with that of formula-fed infants after the first 3 months (Davis Area Research on Lactation in Infant Nutrition and Growth (DARLING) study ${ }^{(19)}$ ). At 1 year of age, breast-fed infants are leaner than formula-fed infants ${ }^{(20)}$. Growth differences that persist throughout the first year are due predominantly to increases in total energy $(+15-23 \%$ in formula-fed infants) and protein $(+66-140 \%$ in formulafed infants) intakes, since breast-fed infants seem to selfregulate their intake at a lower level than formula-fed infants ${ }^{(21)}$. These observations were confirmed by Hediger et al. $^{(22)}$ in the Third National Health and Nutrition Survey (NHANES III) which compared infants who had been exclusively breast-fed for at least 4 months with infants who had been partially or never breast-fed. Infants exclusively breast-fed weighed less at 8-11 months of age, while weight differences disappeared in subsequent age up to 5 years. Accordingly, Rebhan et al. ${ }^{(23)}$ have recently described a 
Table 2. Overview of the proteins in human and bovine milk and their proposed bioactive functions*

\begin{tabular}{|c|c|c|c|}
\hline & Human milk & Bovine milk & Main physiological functions \\
\hline Protein concentration $(\mathrm{g} / \mathrm{l})$ & $10-12 \dagger$ & 33 & \\
\hline \multicolumn{4}{|l|}{$\begin{array}{l}\text { Caseins and whey proteins } \\
\quad \text { (proportion of total protein; \%) }\end{array}$} \\
\hline Caseins & $40 \ddagger$ & $80-86$ & \\
\hline$\alpha$-Casein & 0.06 & 39 & Immunomodulation, anxiolytic properties \\
\hline$\beta$-Casein & 27 & 28 & Ion carrier, potential opioid activities \\
\hline к-Casein & & 19 & Antibacterial activity \\
\hline Whey proteins & $60 \ddagger$ & $14-20$ & \\
\hline$\alpha$-Lactalbumin & 27 & 4 & Antibacterial activity, ion carrier \\
\hline$\beta$-Lactoglobulin & 0 & 11 & \\
\hline Lactoferrin & 18 & Trace & $\begin{array}{l}\text { Immunomodulation, antibacterial activity, } \\
\text { Fe absorption, prebiotic activity, potential } \\
\text { growth-stimulating activity }\end{array}$ \\
\hline Lysozyme & 4.5 & Trace & Antibacterial activity \\
\hline Immunoglobulins & & & Immune protection, antibacterial activity \\
\hline $\lg A$ & $5-10$ & 0.1 & \\
\hline $\lg G$ & $0 \cdot 1$ & $1 \cdot 8$ & \\
\hline $\lg M$ & 0.2 & 0.3 & \\
\hline Serum albumin & $3-4.5$ & 0.9 & \\
\hline \multicolumn{4}{|l|}{ Minor proteins } \\
\hline Amylase & - & - & Improves digestion of starch supplement \\
\hline$\alpha 1$-Antitrypsin & - & - & Limits proteolytic activity of trypsin \\
\hline Bile salt-stimulated lipase & - & - & Improves fat digestion \\
\hline Folate-binding protein & - & - & Facilitates folate uptake \\
\hline Haptocorrin & - & - & Antibacterial activity, vitamin $B_{12}$ absorption \\
\hline Lactoperoxydase & - & - & Antibacterial activity \\
\hline $\begin{array}{l}\text { Cytokines (IL-1 } 1 \beta \text {, IL-6, IL-8, IL-10, } \\
\text { TNF- } \alpha \text {, TGF- } \beta \text {, etc) }\end{array}$ & - & - & Immunomodulation \\
\hline Growth factors (IGF-I, IGF-II, EGF) & - & - & Stimulate mucosal growth \\
\hline $\begin{array}{l}\text { Insulin, adipokines (leptin, adiponectin, } \\
\text { resistin, etc), ghrelin, obestatin }\end{array}$ & - & - & Hormonal activity \\
\hline
\end{tabular}

faster weight gain from the second month of life in infants not or less than 4 months breast-fed in comparison with infants fully or exclusively breast-fed for at least 4 months or longer.

\section{Breast- $v$. formula-feeding: impact on intestinal morphology and physiology}

The main role of intestinal epithelial cells is to finally digest and absorb nutrients from the intestinal lumen. This is particularly true in neonates whose nutrient requirements are enormous to ensure growth during the first months of life. Postnatal epithelial growth and development is poorly defined in humans. However, from animal studies, it appears that extensive changes occur in the small intestine and colon architecture as well as in the hydrolytic and absorptive functions during the postnatal period $^{(24)}$.

\section{Mucosa morphology}

Using endoscopic techniques to obtain biopsies from healthy infants, Thompson et al. ${ }^{(25)}$ compared intestinal morphometry in infants of 2-6 months of age who were entirely breast-fed or formula-fed: although villous area was not affected by the diet, crypt depth was increased by
$30 \%$ in formula-fed infants. This increased depth was accompanied by an increase of mitotic count per crypt of nearly $200 \%{ }^{(25)}$. More extensive studies have been undertaken in rats, also concluding in a trophic effect of formula-feeding $v$. suckling on the intestine. The small intestine and colon weight was increased in formula-fed compared with suckled rats, with higher villous density, longer villi and deeper crypts and a thicker muscle layer all along the small intestine ${ }^{(26-30)}$. Similar to humans, mitotic activity was increased in formula-fed compared with suckled animals ${ }^{(26,30)}$. However, in precocial species, such as the guinea-pig, born more mature than rat pups and therefore more similar to humans, no such gut hypertrophy in response to formula-feeding has been observed $^{(31)}$. In piglets, also believed to be more similar to human neonates, results are contradictory, since formula-feeding for the first $7 \mathrm{~d}$ of life resulted in an early increase in apoptotic index and a decrease in mitotic index but no significant variation in villous length or crypt depth ${ }^{(32,33)}$. In contrast, our unpublished results show a trophic effect (increased weight and density) of $21 \mathrm{~d}$ of formula-feeding compared with $21 \mathrm{~d}$ of suckling in piglets (I Le Huërou-Luron, G Boudry, A Morise and $B$ Sève, unpublished results; Fig. 2). The effect of formula $v$. breast-feeding on colonic mucosa architecture either in humans or in animal models is not known. 

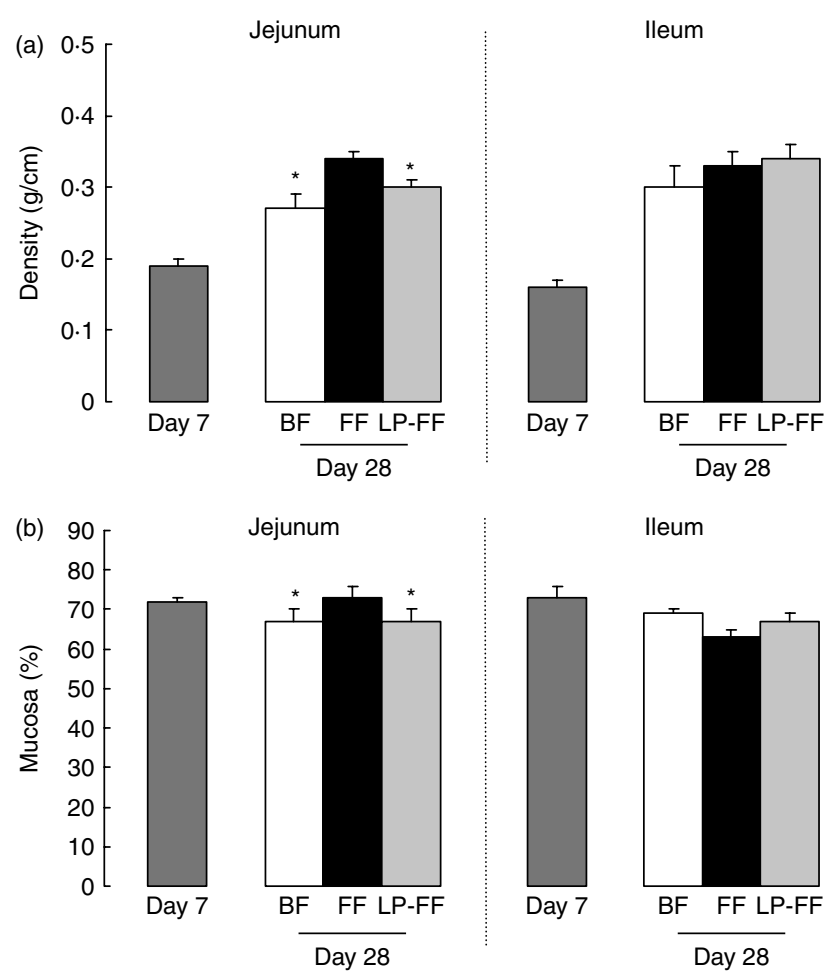

Fig. 2. Effect of decreasing the protein content of formula on jejuna and ileal density $(\mathrm{g} / \mathrm{cm}$ length) (a) and proportion of mucosa of the total wall thickness in jejunum and ileum (b) in piglets. Piglets were either breast-fed (BF) or formula-fed from day 7 to day 28 of life with a standard formula (FF) or a low-protein formula providing the same level of proteins as sows' milk (LP-FF). Values are means, with standard errors represented by vertical bars. Reducing the protein content of the formula prevented the hypertrophic effect of formula-feeding in the jejunum. * Mean value was significantly different from that of the FF group $(P<0.05)$.

\section{Hydrolytic and nutrient absorption capacities}

In most species, intestinal lactase activity decreases, while maltase and sucrase activities increase with postnatal age, but with species variations in the timing of these changes. In man, postnatal lactase development resembles that of other animal species while intestinal maltase and sucrase activities develop in utero and reach adult values before the end of the second trimester of gestation ${ }^{(34,35)}$. Studies in animal models all agree on a precocious maturation of intestinal disaccharidase activities induced by formulafeeding; sucrase and maltase specific activities increase while lactase activity declines more rapidly in formula-fed compared with suckled animals, both in rats ${ }^{(26,27,30)}$ and guinea-pigs $^{(31)}$. The effect of formula-feeding on postnatal development of peptidases (dipeptidyl-peptidase IV, aminopeptidase $\mathrm{A}$ and $\mathrm{N}$ ) has not been investigated. Similarly, the effect of formula- $v$. breast-feeding on nutrient transporter expression at the enterocyte level has not been investigated.

Data on the effect of formula-feeding on human intestine architecture and on hydrolysis and absorption function are very limited and it may be difficult to extrapolate the results obtained in animal models due to species differences. However, it seems that formula-feeding induces gut hypertrophy and accelerates maturation of hydrolytic capacities. Those two phenomena may result from an adaptation of the intestine to match the nutrient composition of formulas. It might therefore result in higher absorption rates of nutrients in formula-fed compared with breast-fed neonates for the same food intake. This raises the question of how far the mechanisms controlling nutrient homeostasis in the whole body still not fully mature at that age adapt to this higher influx of nutrients in the portal vein.

\section{Breast- $v$. formula-feeding: impact on gut microbiota}

The neonatal intestinal microbiota is a complex ecosystem composed of numerous genera, species and strains of bacteria, protozoa and fungi. This microbiota performs a variety of activities (nutritive, metabolic and protective functions) that affect both the intestinal physiology, and the whole-body metabolism and immunity. Indeed, germ-free piglets exhibit a lower intestinal mass, a thinner intestinal mucosa, shorter crypts, narrower and longer villi, and a lower epithelial cell turnover and mucus synthesis rate than conventionally reared animals ${ }^{(36)}$. Conventional mice also have $40 \%$ higher body fat content than germ-free mice, probably due to the increased energy supply from SCFA produced by the microbiota ${ }^{(37)}$. The establishment of the gut microbial population is a complex process influenced by microbial and host interactions and by external and internal factors. It starts at birth, where bacteria establish in succession during the first years of life until an adult-type highly complex microbiota has been achieved. The first bacteria to establish in the neonatal gut are usually aerobic or facultative anaerobic bacteria, such as enterobacteria, enterococci and staphylococci. During their growth they consume $\mathrm{O}_{2}$ and change the intestinal milieu, allowing the proliferation of anaerobic bacteria. Bifidobacteria, Clostridia and Bacteroides are among the first anaerobes to be established in the gut. As more $\mathrm{O}_{2}$-sensitive species establish and the complexity of the microbiota increases, the population sizes of aerobic and facultative bacteria decline and bifidobacteria usually become the predominant flora in human infants.

\section{Composition of the faecal microbiota}

Formula-fed infants also develop a complex microbiota but with facultative anaerobes, Bacteroides and Clostridia at higher levels and frequency than in breast-fed infants. A bifidobacterial predominance is also common in formulafed infants, although in lower number and frequency compared with breast-fed infants of the same age group $^{(38,39)}$. Some formula-fed babies also exhibit predominance of Bacteroides and enterococci. The proportion of the different bifidobacterial species (Bifidobacterium breve, B. adolescentis, B. longum, B. bifidum, B. infantis) does not seem to be significantly altered by formulafeeding ${ }^{(40)}$. Similarly, the predominant group within the Bacteroides genera remains the $B$. fragilis group as in breast-fed infants. Finally, the higher count and frequency of Clostridia in formula-fed infants is accompanied by a predominance of Clostridium perfringens while the most common species is usually $C$. difficile in breast-fed infants ${ }^{(38)}$. 


\section{Metabolic characteristics of the microbiota}

Higher amounts of faecal SCFA have been found in formula-fed compared with breast-fed infants. In breast-fed infants, acetic acid accounts for most of the total SCFA. Formula-fed infants also have acetate as the predominant SCFA in faeces, but propionate and to a lesser extent butyrate have higher molar ratios compared with breast-fed infants $^{(38,41)}$. This difference in faecal SCFA profile could be due to the variability in the intestinal microbiota between the two feeding groups and their possible difference in the ability to ferment carbohydrates. However, in vitro fermentation capacities for simple sugars and oligosaccharides of the faecal microbiota of breast-fed and formula-fed infants seem to be similar ${ }^{(42)}$.

\section{Mucosa-adherent bacteria}

Because of ethical issues, studies aimed at investigating the effect of formula- $v$. breast-feeding on human microbiota have exclusively concentrated on the faecal microbiota. However, although reflecting intestinal and colonic contents, faecal samples do not fully represent luminal microbiota. Specifically they do not inform on the mucosa-adherent bacteria which interact with intestinal epithelial cells and may modulate intestinal physiology and the immune system. One study examined the effect of formula-feeding $v$. suckling in rats on adherent bacteria in the small intestine, caecum and colon of pups. Caecal and colonic adherent bacteria were not affected by formula-feeding but the total number of bacteria adherent to the small intestine and especially enterobacteria, Enterococcus and Streptococcus counts were increased in formula-fed pups ${ }^{(43)}$. Whether these changes in adherent bacteria of the small intestine affect intestinal physiology and immune system is, however, not known.

Taken together, these results show that, in contrary to what is commonly believed, the differences in the microbiota of breast- and formula-fed infants are not striking. However, many studies have linked intestinal and metabolic diseases in adulthood with disturbed microbiota. The role of the microbiota in the development of atopic disease or even type 1 diabetes has been underlined ${ }^{(44,45)}$, inflammatory bowel disease and irritable bowel syndrome are thought to originate from microbiota dysbiosis ${ }^{(46)}$, and obesity and type 2 diabetes are associated with decreased microbial diversity in the human gut, and particularly low levels of Bacteroides ${ }^{(47)}$. Therefore, although being minor, formula-feeding-induced microbial alterations might be involved in the aetiology of these adulthood diseases.

\section{Breast- $v$. formula-feeding: impact on gut barrier function}

The epithelium lining the intestine plays an integrated role in maintaining intestinal barrier function and constitutes one of the first lines of defence against infectious agents and allergens. Enhanced uptake of molecules in the intestinal mucosa may have a role in the maturation of the immune system and the acquisition of oral tolerance. On the other hand, increased permeability leaves neonates more susceptible to infection, inflammation and hypersensitivity.
The exact relationship between variations in intestinal permeability or bacterial translocation and education or probing of the gut-associated immune cells, especially in neonates, is still not completely understood and is an area of intensive research and debate. Evidence of increased intestinal permeability in early life leading to a higher susceptibility to stress and/or inflammation later on in adult life has been demonstrated by studies on neonatal stress in rats $^{(48-50)}$. However, several studies support the idea of a role of bacterial translocation early in life in the education of the intestinal immune system ${ }^{(51,52)}$.

\section{Epithelial permeability}

Measurement of intestinal permeability in vivo in human neonates consistently reveals a higher permeability in formula-fed compared with breast-fed neonates, independently of the fetal age at birth. More precisely, the time-course of changes in permeability with age seems to be modified by formula-feeding. Indeed, in healthy term neonates, gut closure (corresponding to a decrease in permeability with age between day 1, day 7 and day 30 of life) was delayed in formula-fed compared with breast-fed babies, resulting in a higher permeability at day 7 of life but similar permeability value at day $30^{(53)}$. Similarly, the decline in intestinal permeability measured in breast-fed term neonates during the first week of life was not observed in formula-fed neonates ${ }^{(54)}$. Studies in rabbits and rats corroborate this delayed gut closure in formula-fed animals: rabbits formula-fed during 1 week after birth but not 2 weeks exhibit a higher permeability to macromolecules than suckled pups ${ }^{(55)}$. In rats where gut closure occurs later in the neonatal period (coordinated to weaning at age 17-21 d), formula-feeding with cows' milk hydrolysate or soyabean formula at the moment of this intestinal closure prevents this decrease of intestinal permeability to macromolecules ${ }^{(56)}$. In piglets, we did not observe such an effect of formula-feeding compared with sow-suckling on postnatal development of jejunal and ileal permeability. However, despite the absence of difference in intestinal permeability between suckled and formula-fed piglets, ZO1 mRNA abundance, one of the major proteins regulating tight junction permeability, was reduced by half in formula-fed animals (Fig. 3; G Boudry, A Morise, B Sève and I Le Huërou-Luron, unpublished results). This lower expression of ZO1 together with unchanged permeability values suggest that others mechanisms are activated to warrant normal permeability (up-regulation of others proteins, involvement of the enteric nervous system, etc).

\section{Bacterial translocation}

Bacterial translocation, defined as the passage of viable bacteria from the gastrointestinal tract to the mesenteric lymph nodes and other systemic organs, is another aspect of intestinal barrier function. Even if adherence of bacteria to the mucosal surface remains the main factor determining bacterial translocation, the nature of the intestinal mucosal barrier of the host influences the incidence of bacterial translocation $^{(57)}$. Data on the effect of formula-feeding $v$. suckling on bacterial translocation consistently demonstrate a higher incidence of bacterial translocation in formula-fed 

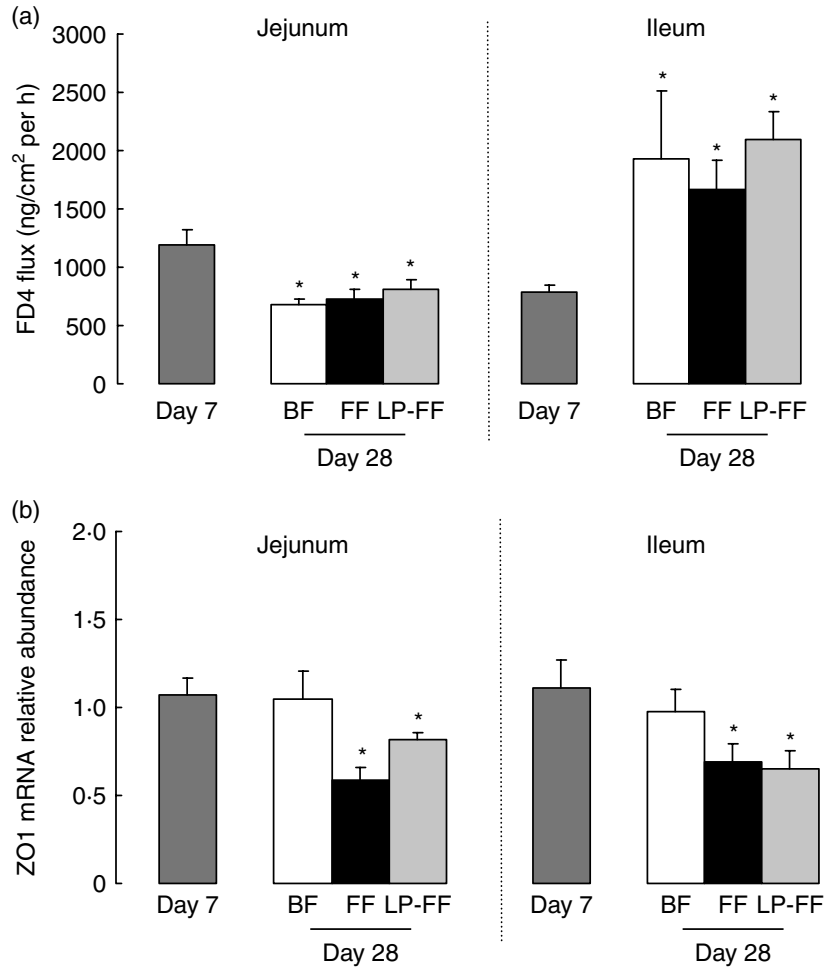

Fig. 3. Effect of decreasing the protein content of formula on jejunal and ileal permeability (a) and ZO1 mRNA expression (b) in piglets. Piglets were either breast-fed (BF) or formula-fed from day 7 to day 28 of life with a standard formula (FF) or a low-protein formula providing the same level of proteins as sows' milk (LP-FF). Values are means, with standard errors represented by vertical bars. Reducing the level of protein in the formula did not modify the effect of formulafeeding on intestinal permeability and ZO-1 mRNA expression. * Mean value was significantly different from that at day $7(P<0.05)$.

v. suckled neonates either in rabbits suckled or formula-fed for $3 \mathrm{~d}^{(58)}$ or $7 \mathrm{~d}^{(59)}$ or in rats suckled or formula-fed for $3-5 \mathrm{~d}^{(60)}$. Yet again, the postnatal pattern of incidence of bacterial translocation seems to be affected by formulafeeding: while bacterial translocation incidence peaks at day 7 of life and has disappeared at day 14 in suckled rats, systemic bacterial translocation was still observed in $50 \%$ of formula-fed rats at day $14^{(43,57)}$.

In conclusion, both human and animal model studies agree on a change in the postnatal development of barrier function when formula-feeding occurs, resulting in a higher molecular permeability at some point during the neonatal period in formula-fed $v$. breast-fed neonates. Even if no immediate harmful consequences of such an enhanced permeability and bacterial translocation have been described, this high intestinal permeability and therefore increase load of antigens and bacteria during the neonatal period may profoundly affect the education of the immune system, especially in terms of oral tolerance acquisition, and have long-term consequences later in life.

\section{Breast- $v$. formula-feeding: impact on enteroendocrine cells}

Enteroendocrine cells are specialised cells dispersed among the epithelial cells of the gastrointestinal tract. Even though they represent less than $1 \%$ of the entire epithelial cell population in the gut, they constitute the largest endocrine organ in the human body, secreting a variety of hormones or signalling molecules. There are over twenty different enteroendocrine cells, including cells secreting gastrin ( $\mathrm{G}$ cells), ghrelin ( $\mathrm{P}$ or $\mathrm{X}$ cells), somatostatin (D cells), cholecystokinin (I cells), serotonin (enterochromaffin cells), glucose-dependent insulinotropic peptide (GIP; K cells), glucagon-like peptides (GLP; L cells) and peptide YY (L cells). They respond to luminal constituents by releasing secretory products that activate nearby or distant targets. They appear early in fetal life and their secretion is believed to play a significant role in the early development of the gut and pancreas ${ }^{(61)}$. There is good evidence that the initiation of enteral feeding is an important environmental trigger which provokes massive surges in the concentration of these peptides in the first postnatal days. The nature of the diet (either breast-milk or formula) may then be critical even if poorly investigated. The first meal of breast-milk elicits both gastrin and enteroglucagon (GLP) secretions, but no GIP secretion in babies aged $4-6 \mathrm{~h}$, whereas a first meal of $10 \%$ glucose induces gastrin secretion only ${ }^{(62)}$. In babies aged $6 \mathrm{~d}$, formula-fed infants have a greater GIP response to a meal than breast-fed infants ${ }^{(63)}$. At 9 months of age, postprandial secretions of GIP and cholecystokinin are smaller in breast- $v$. formula-fed infants, whereas gastrin secretion is higher and no difference occurs for GLP secretion $^{(64)}$. Therefore, the nature of the diet (breast-milk v. formula) has an impact on the response pattern of enteroendocrine cells during the milk period. Consequences on the maturation of the gut and pancreas in the short term and on their function later on are at present unknown.

\section{Breast- $v$. formula-feeding: impact on pancreatic exocrine function}

At birth, the pancreas is far from mature and undergoes rapid development during early life. Most enzyme activities are detectable in human fetal tissue from the 20th week of gestation and exocrine secretion may begin around the fifth month of gestation ${ }^{(65)}$. Enzyme activities gradually increase during fetal life and thereafter postnatally. The impact of nutrition on the functional development of the exocrine pancreas is commonly recognised but only one study compared the impact of formula- $v$. breast-feeding on pancreas exocrine secretion of human neonates ${ }^{(66)}$. They concluded that breast-feeding is associated with lower faecal chymotrypsin activity (as an indicator of pancreatic exocrine function) that may be related to the lower protein content of human milk. In piglets, formula-feeding during the first week of life induced a decrease in most proteolytic activities and in lipase activity in the pancreatic tissue ${ }^{(67)}$. Measurements of enzyme activities at the tissue level are the result of the balance between pancreatic protein synthesis and protein release via the pancreatic juice. Whether these modifications resulted from an increased release of pancreatic enzymes in the intestinal lumen of piglets or not is unknown. Therefore, data on the impact of formulafeeding on the development of exocrine pancreas in humans as well as on animal species are rare and insufficient to 
conclude on the developmental profile of the hydrolytic capacities of formula-fed infants.

\section{Breast- $v$. formula-feeding: impact on pancreatic endocrine function}

The endocrine pancreas plays a key role in the regulation of glycidic homeostasis through the secretion of insulin, the unique hypoglycaemic hormone, and glucagon. In the majority of mammals, a rapid pancreatic growth is observed during the neonatal period and dietary influences in critical windows of development could account for long-term metabolic consequences, especially when comparing formula- and breast-feeding.

\section{Metabolic adaptation and glucose homeostasis at birth}

Before birth, the fetus is entirely dependent on continuous transplacental nutrient transfer from the maternal circulation $^{(68)}$. The fetal pancreas develops in the late first to early second trimester, producing measurable insulin concentration by mid-gestation ${ }^{(69)}$. The components of the glucosesensing and insulin-secretion pathways (glucokinase, $\mathrm{K}_{\mathrm{ATP}}^{+}$ channels and L-type $\mathrm{Ca}^{2+}$ channels) are present in the human fetus as early as $14-18$ weeks of gestation, but the insulin secretory responses to glucose are attenuated at this early stage of gestation ${ }^{(70,71)}$. There is a gradual increase in basal insulin concentration and glucose- and arginineinduced secretion toward term, the biphasic insulin release being present only after birth ${ }^{(69,70)}$.

With the closure of the umbilical cord at birth, the continuous transplacental supply of nutrients is abruptly disrupted, and blood glucose falls rapidly, reaching a nadir by $1 \mathrm{~h}$ of age and then rising to stabilise by $3 \mathrm{~h}$ of age even in the absence of any exogenous nutritional intake ${ }^{(72)}$. Due to the stress of the birth process mediated through the catecholamine surge, insulin level falls and there is a marked surge in plasma immunoreactive glucagon level ${ }^{(73,74)}$, leading to mobilisation of glycogen and neoglucogenesis ${ }^{(75)}$. The catecholamine surge also activates lipolysis and lipid oxidation, resulting in increases in the levels of glycerol and NEFA. NEFA are used to generate ketone bodies, which provide an alternative source of fuel. Maintenance of normoglycaemia in the newborn infant is then dependent upon the exogenous glucose provided by the hydrolysis of milk lactose, and endogenous glucose production through gluconeogenesis. The secretion of regulatory peptides from the gut and pancreas in response to enteral milk feeding may have a fundamental role in initiating and regulating the cascade of developmental changes needed for the utilisation of nutrients which occurs after birth, enhancing the importance of the nature of the milk.

\section{Glucose, insulin, C-peptide profiles and entero-insular function after formula- v. breast milk}

Glucose is the major stimulator triggering insulin secretion, but intestinal hormones such as GIP and GLP-1, called incretins, are potent stimulators of glucoseinduced insulin secretion, giving rise to the concept of an entero-insular axis. C-peptide, co-released with insulin but not extracted by the liver, is usually taken as a systemic marker of insulin secretion.

The nature of feeding affects neonatal metabolic profiles. Healthy term breast-fed babies aged up to 1 week old have significantly lower blood glucose concentrations than those who are formula-fed, which may reflect the low energy content of breast milk in the first postnatal days. However, their ketone body concentrations are higher than those of formula-fed infants ${ }^{(76)}$. The compensatory provision of alternative fuels may constitute a normal adaptive response to a transient low nutrient intake during the establishment of breast-feeding, resulting in breast-fed infants tolerating lower plasma glucose levels without any significant clinical manifestations or sequelae ${ }^{(77)}$. Indeed, the neonatal brain has an enhanced capability to use ketone bodies, providing glucose-sparing fuel to the brain and protecting neurological function in the case of hypoglycaemia ${ }^{(78)}$. Alternatively, the raised ketone body concentrations may be secondary to a direct ketogenic effect of breast-milk, by virtue of its lipase content allowing the delivery of fatty acids to the liver via the portal venous system ${ }^{(76)}$.

Several hormone systems are functionally active at birth and are stimulated by the first meal. In piglets, insulin response to an intravenous glucose infusion increases with age during the first $24 \mathrm{~h}$ of life, showing a continuous and prompt maturation of $\beta$-cells after birth; however, the maturation of the islets is markedly augmented by enteral feeding, being much slower in starved animals ${ }^{(79)}$. Improvement of glucose tolerance in piglets during the first day of life is dependent on milk intake rather than on age ${ }^{(79)}$, demonstrating the importance of the nature of the milk in the short-term glucose metabolism regulation of neonates. In rats, while glucose elicits no (19-d-old fetus) or poor (21-d-old fetus) insulin secretion from fetal $\beta$-cells, a marked effect of glucose on insulin secretion was observed in the pancreas of 3-d-old rats, indicating that the neonatal period is crucial for the maturation of the glucose-sensing mechanism in $\beta$-cells ${ }^{(80)}$ and that the nature of milk during this period may have major consequences on the long-term metabolic outcomes. There is, however, little information on the normal metabolic responses to the physiological stimulus of breast-milk compared with formula. Lucas et al. ${ }^{(63)}$ showed that in 6-d-old term infants $(4 \%$ of the milk period), formula induced greater insulin and GIP responses than breast-milk but similar postprandial blood glucose elevation. One interesting piece of information from this study is that by 1 week of age, the postprandial GIP secretion by the enteroendocrine K-cells had become effective. The authors postulated that the higher GIP concentration after formula-feeding could have accounted for the enhanced insulin release. The unchanged postprandial glucose excursion has, however, to be taken cautiously, since the first postprandial blood sample was taken $55 \mathrm{~min}$ after the beginning of the feed and an earlier peak of glycaemia may not have been screened with such a delayed sample. Another large-scale study on infants aged $7 \mathrm{~d}$ confirmed that formula-fed infants have higher postprandial insulin concentration than breast-fed infants, even though glucose was not raised ${ }^{(81)}$. Here again, the first sample was performed within the first hour after the last meal and may have missed an earlier glucose or insulin peak. 
(a)

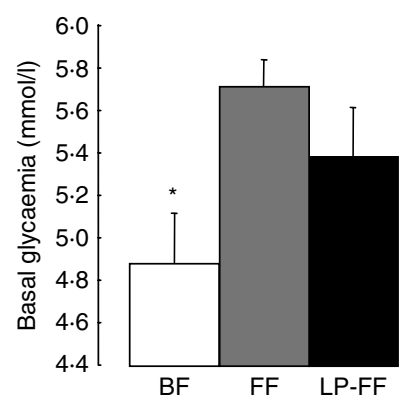

(b)

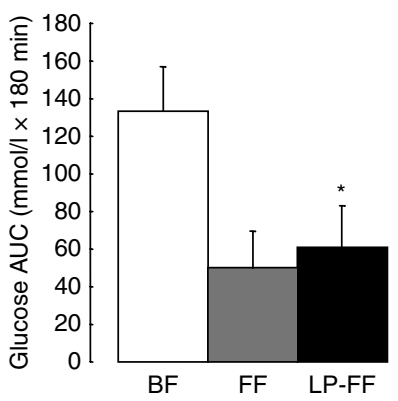

Fig. 4. Basal glycaemia (a) and area under the postprandial timecourse curve (AUC) of glucose response above basal values (b) in breast-fed, formula-fed and low-protein formula-fed piglets. Piglets were either breast-fed (BF) or formula-fed from day 7 to day 28 of life with a standard formula (FF) or a low-protein formula providing the same level of protein as sows' milk (LP-FF). Values are means, with standard errors represented by vertical bars. Basal glycaemia was lower in BF piglets than in FF piglets and reducing the protein content of the formula restored the glycaemia to the level of the BF piglets. Postprandial glucose AUC was higher in BF compared with formula-fed piglets, whatever the protein content of the formula (FF and LP-FF). * Mean value was significantly different from that of the FF group $(P<0.05)$.

We performed postprandial recordings of glycaemia, insulinaemia and incretins later in the suckling period (30\% of the natural milk period) in piglets aged $21 \mathrm{~d}$ either suckled or formula-fed. We demonstrated that suckled piglets had lower basal glycaemia than formula-fed piglets and that sows' milk induced higher postprandial glucose, but lower GIP and enteroglucacon (GLP-1) responses and no difference in insulin response compared with formula (Figs. 4 and 5; S Blat, A Morise, A Sauret, C Magliola, K Macé, I Le Huërou-Luron and B Sève, unpublished results). Such discrepancies with earlier studies in infants may be due to the period of feeding investigated (30 v. $4 \%$ of the milk period). However, a study in babies from 3 to 6 months old (50-100\% of the feeding period) showed a

higher urinary excretion of C-peptide, illustrating a higher insulin secretion, in formula-fed compared with breast-fed babies $^{(82)}$. Furthermore, a study in 9-month-old babies (more than $100 \%$ of the recommended feeding period) demonstrated that basal glucose, insulin and incretin concentrations were identical in formula-fed and exclusively breast-fed infants while the postprandial responses were significantly smaller in breast-fed infants whose plasma concentrations of insulin, GIP and cholecystokinin were lower than in the formula-fed infants ${ }^{(64)}$. In conclusion, the metabolic responses to breast-milk $v$. formula display differences, whatever the period of feeding or suckling and the animal models, enhancing the plausibility of long-term metabolic consequences.

For ethical reasons, no information comparing pancreas development in breast-fed $v$. formula-fed infants is available, even though differences in insulin secretion have been demonstrated. Similarly there are no data from experimental animal studies. In piglets aged $28 \mathrm{~d}$, we recently found a higher percentage of endocrine tissue due to a higher diameter of the islets in suckled compared with formula-fed piglets (S Blat, A Morise, A Sauret, C Magliola, K Macé, I Le Huërou-Luron and B Sève, unpublished results). This was associated with the higher postprandial glycaemia in suckled $v$. formula-fed piglets described above.

\section{Towards improved formula to avoid disadvantageous formula-feeding impact on intestinal and pancreatic structure and functions}

\section{Protein content}

Cows' milk protein is the major source of protein in an infant formula. Present recommendations set a minimum protein quantity of $0.43 \mathrm{~g} / 100 \mathrm{~kJ}(1.8 \mathrm{~g} / 100 \mathrm{kcal})$, similar to human breast milk. However, due to differences in protein and amino acid digestibility, bioavailability and efficiency of utilisation between human milk and formula, the amount of protein per energy content is generally higher in formula
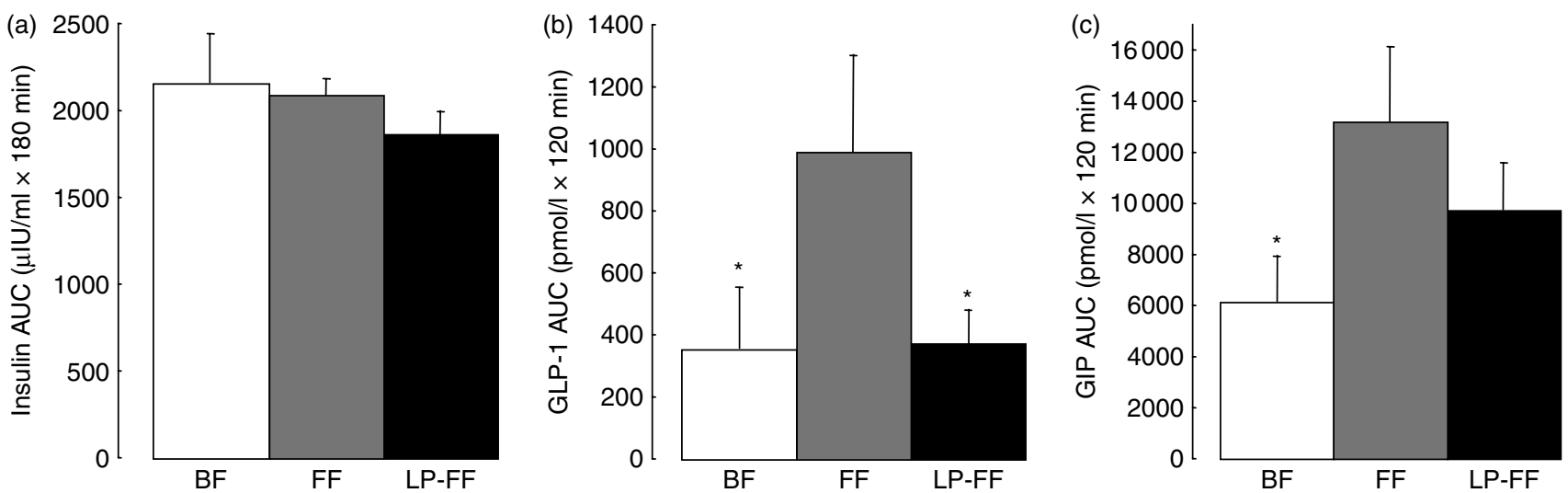

Fig. 5. Area under the postprandial time-course curve (AUC) of insulin (a), glucagon-like peptide-1 (GLP-1) (b) and glucose-dependent insulinotropic polypeptide (GIP) (c) responses above basal values in breast-fed, formula-fed and low-protein formula-fed piglets. Piglets were either breast-fed (BF) or formula-fed from day 7 to day 28 of life with a standard formula (FF) or a low-protein formula providing the same level of protein as sows' milk (LP-FF). Values are means, with standard errors represented by vertical bars. The diet did not modify postprandial insulin concentration. FF piglets had higher postprandial GLP-1 and GIP concentrations than BF piglets and lowering the protein content of the formula normalised postprandial GLP-1 and GIP concentrations compared with BF piglets. * Mean value was significantly different from that of the FF group $(P<0.05)$. 
than in human milk to meet the protein and amino acid requirements of infants (up to $0.60 \mathrm{~g} / 100 \mathrm{~kJ}(2.5 \mathrm{~g} / 100 \mathrm{kcal})$ for the formula), i.e. up to $40 \%$ more $\operatorname{protein}^{(83,84)}$. The present tendency is to reduce protein content in formulas towards the minimal level, but its impact on intestinal function has not been investigated.

Using the piglet model, we observed that reducing the protein content of formula towards sows' milk protein level prevented the trophic effect of a standard formula containing $50 \%$ more protein than sows' milk observed in the jejunum (Fig. 2; I Le Huërou-Luron, G Boudry, A Morise and B Sève, unpublished results) but did not modify the effect of formula-feeding on epithelial barrier function (Fig. 3; G Boudry, A Morise, B Sève and I Le Huërou-Luron, unpublished results). It also changed the intestinal lactase and pancreatic trypsin activities towards a maternal milk profile.

In the same piglet model, reducing the protein content of the formula tended to lower the basal glycaemia to a level more similar to that of suckled piglets but did not modify the formula-induced reduction of postprandial glycaemia (Figs. 4 and 5; S Blat, A Morise, A Sauret, C Magliola, K Macé, I Le Huërou-Luron and B Sève, unpublished results). Moreover lower protein content of the formula lowered the postprandial GLP-1 and GIP secretion to levels identical to suckled piglets (Fig. 5). The structure of the endocrine pancreas at the end of the milk period was, however, identical with the two formulas.

\section{PUFA}

The long-chain PUFA, arachidonic acid and DHA, are essential structural lipid components of biomembranes and are crucial for normal central nervous system and retina development. Supplementation of formula with these longchain PUFA has been encouraged to enhance DHA and arachidonic acid status in blood, brain and retina lipids to similar levels of the breast-fed infant. The clinical trials in preterm and healthy full-term infants demonstrated benefits of formula supplementation with DHA and arachidonic acid for the development of visual acuity up to 1 year of age and of complex neural and cognitive functions. At the intestinal level, few trials have evaluated the effect of supplementation of formulas with long-chain PUFA. The only report concluded in no difference in intestinal permeability between long-chain PUFA-supplemented and non-supplemented formula-fed babies ${ }^{(85)}$.

\section{Prebiotics}

Human milk contains a high amount of complex indigestible oligosaccharides (up to $8 \mathrm{~g} / \mathrm{l}$ ), which are not found in formulas and are thought to be of benefit for the breast-fed infants. In an attempt to provide formula-fed infants with similar benefits, some companies have started supplementing their formulas with oligosaccharides that are, however, structurally different from human oligosaccharides: fructo-oligosaccharides, galacto-oligosaccharides and inulin. The results from several studies clearly demonstrate that these prebiotic mixtures specifically stimulate the growth of bifidobacteria and lactobacilli and reduce the growth of pathogens. The SCFA pattern also tends to be similar to that of breast-fed infants (for a review, see Farano et al. ${ }^{(86)}$ ). While the effect of these prebiotics on intestinal microbiota has been and is still largely explored, few studies have investigated the actual effect of these supplements on intestinal physiology. One study compared intestinal permeability of neonates breast-fed or fed formulas with or without prebiotics. The authors did not observe difference in the lactulose:mannitol ratio between the two groups ${ }^{(85)}$. The effect of a mixture of galactooligosaccharides and inulin on intestinal structure and permeability as well as translocation has been investigated in formula-fed rats. The supplemented group exhibited a higher number of mucosa-associated enterobacteria and an increased incidence of translocation compared with the non-supplemented and the mother-reared group. Epithelial colonic permeability assessed in Ussing chambers was not different amongst groups although ZO1 mRNA expression was reduced by $40 \%$ in the supplemented group compared with the non-supplemented ${ }^{(87)}$. A similar galactooligosaccharides-induced increase in bacterial translocation has already been observed in adults ${ }^{(88,89)}$ but whether such a phenomenon in the neonate could be beneficial or not for the maturation of the immune system has not been determined.

\section{Secretory $\operatorname{Ig} A$}

Breast milk contains high levels of secretory IgA (0.5 to $1.2 \mathrm{~g} / \mathrm{l})$, higher than in serum. Secretory IgA prevents attachment and invasion of pathogens by competitively binding and neutralising bacterial antigens. Supplementation of formula with human IgA decreases the incidence of translocation to the liver and spleen in rabbits ${ }^{(90)}$. Similarly, supplementation of formula with $\operatorname{IgA}$ (but not with $\operatorname{IgG}$ ) for $7 \mathrm{~d}$ decreases the incidence of bacterial translocation to the mesenteric lymph nodes in rabbits to a level similar to that in suckled animals. The passage of labelled Escherichia coli $\mathrm{C} 25$ across the ileal epithelium in vitro was reduced in the IgA-supplemented formula-fed animals compared with the non-supplemented or IgG-supplemented animals, suggesting that the action of $\operatorname{IgA}$ was at the luminal or epithelial level rather than in the mesenteric lymph nodes themselves ${ }^{(91)}$.

\section{Lactoferrin}

Lactoferrin concentration in breast milk varies with lactation stage: from about $10 \mathrm{~g} / \mathrm{l}$ in colostrum to $3 \mathrm{~g} / \mathrm{l}$ in mature milk. Lactoferrin antimicrobial activity is due partly to its high affinity for $\mathrm{Fe}$. The combination of $\mathrm{Fe}$ and lactoferrin in milk modulates the growth and aggregation of pathogenic bacteria, and inhibits both bacteria and viruses by binding to cell and viral particles. Lactoferrin also possesses anti-inflammatory properties and seems to be involved in phagocytic killing and immune responses. The effect of lactoferrin supplementation of formula to modulate faecal microbiota seems limited, although some 'bifidogenic' effect was reported ${ }^{(92,93)}$. Similarly, addition of lactoferrin in formula did not affect bacterial translocation in rabbits ${ }^{(91)}$. Nevertheless, a growth factor effect of lactoferrin has been reported in in vitro or ex vivo devices: 
supplementation of formula with human lactoferrin increases thymidine incorporation into the DNA in a rat crypt cells bioassay ${ }^{(94)}$; lactoferrin also increases proliferation and differentiation in various intestinal epithelial cell lines ${ }^{(95,96)}$. However, no in vivo assay has been performed.

\section{Growth factors}

Human breast milk contains various factors such as epidermal growth factor (EGF; range 30-100 $\mu \mathrm{g} / \mathrm{l}$ ), insulin-like growth factor-I (IGF-I; range $6-8 \mu \mathrm{g} / \mathrm{l}$ ) or transforming growth factor- $\beta$ (range $1-2 \mu \mathrm{g} / \mathrm{l}$ ) that are suspected of modulating intestinal growth and maturation. Rat pups fed a formula supplemented with pharmacological or physiological doses of EGF for 3-4 d showed an increased intestinal cell proliferation compared with rats fed the nonsupplemented formula ${ }^{(97,98)}$. Other studies have investigated the effect of EGF with parenteral administration, which makes it difficult to conclude on the beneficial effect of supplementing formulas with this growth factor. It is, however, interesting to notice that subcutaneous treatment of formula-fed rabbits with EGF significantly reduced bacteria translocation to levels similar to those in suckled rabbits ${ }^{(99)}$. IGF-I might also have a trophic effect, since feeding piglets with formula supplemented with pharmacological doses of recombinant human IGF-I increases enzymes (lactase and maltase) and villous height of the small intestine ${ }^{(100)}$ compared with non-supplemented animals. Results are not so clear-cut when physiological doses of IGF-I are provided to young piglets ${ }^{(101)}$.

\section{Nucleotides}

Human breast milk naturally contains free nucleotides $(50-150 \mu \mathrm{mol} / \mathrm{l})$ which can be added in formulas. Various studies have examined the effect of dietary nucleotides on intestinal structure and function in adults ${ }^{(102)}$, concluding with a trophic effect of nucleotides. However, few studies have examined the effect of supplementing formula with those compounds on intestinal structure of the neonate. The effects of nucleotide-supplemented formulas on infant microbiota are contradictory: some clinical trials observed a bifidogenic effect of nucleotides on faecal microbiota ${ }^{(103)}$ while others did not ${ }^{(104)}$. Intestinal permeability and pancreatic enzyme secretion were also not modified by the addition of nucleotides in the formula of neonates ${ }^{(66,85)}$.

\section{Concluding remarks}

Clinicians have long noticed that infants fed breast milk display better resistance to illness during the first year of life. The more recent awareness of the long-term health benefits of breast-feeding has re-stimulated research on formula composition which must provide both nutrition and support for functional development of organs. Changes in lifestyle during recent decades, including nutritional habits of nursing mothers that may influence breast-milk composition, duration of breast-feeding and the physiological properties of some molecules present in the breastmilk as well as formula composition are also taken into account. Surprisingly incomplete attention has been paid to the role of breast-feeding $v$. formula-feeding on the functional development of the digestive tract, in spite of its main role in processing dietary molecules into available nutrients for the organism, allowing their utilisation by peripheral tissues, and in regulating the flux of antigenic materials that participate in the maturation of gut-associated lymphoid tissue. One major issue in human studies on the effect of breast- $v$. formula-feeding on the digestive tract function is the great number of confounding factors which are difficult to circumvent, such as quantification of food intake in breast-fed infants, the very variable length of exclusive breast-feeding and the great variability of the composition of formulas. Animal models are of great help to control some of these confounding factors even if controlling food intake in suckled animals is difficult too. Artificial rearing on formula is also not always possible due to immaturity at birth of some species, and is time consuming. Another challenge of animal studies is to be able to provide the pups with artificial milks as similar as possible to maternal milks. However, the need for such studies is crucial to better understand the mechanisms involved in the short- and longer-term benefits of breastfeeding $v$. formula-feeding.

\section{Acknowledgements}

This research received no specific grant from any funding agency in the public, commercial or not-for-profit sectors.

All authors contributed equally to the preparation of this paper.

There are no conflicts of interest.

\section{References}

1. United Nations Children's Fund (2006) 1990-2005. Celebrating the Innocenti declaration on the protection, promotion and support of breastfeeding. Past achievements, present challenges and the way forward for infant and young child feeding. Second edition. http://www.unicef-irc.org/ homepages/files/documents/f_7.pdf (accessed July 2009).

2. Hoddinott P, Tappin D \& Wright C (2008) Breast feeding. BMJ 336, 881-887.

3. Horta BL, Bahl R \& Martines JC, et al. (2007) Evidence on the long-term effects of breast-feeding: systematic reviews and meta-analyses. WHO Library Cataloguing-inPublication Data. http://www.who.int/child_adolescent_ health/documents/9241595230/en/ (accessed July 2009).

4. Agostoni C, Braegger C, Decsi T, et al. (2009) Breastfeeding: a commentary by the ESPGHAN Committee on Nutrition. J Pediatr Gastroenterol Nutr 49, 112-125.

5. Dewey KG, Heinig J \& Nommsenrivers LA (1995) Differences in morbidity between breast-fed and formulafed infants. J Pediatr 126, 696-702.

6. Howie PW, Forsyth JS, Ogston SA, et al. (1990) Protective effect of breast feeding against infection. BMJ 300, 11-16.

7. Saarinen UM \& Kajosaari M (1995) Breastfeeding as prophylaxis against atopic disease: prospective follow-up study until 17 years old. Lancet 346, 1065-1069.

8. Savilahti E \& Saarinen KM (2009) Early infant feeding and type 1 diabetes. Eur J Nutr 48, 243-249.

9. Mayer EJ, Hamman RF, Gay EC, et al. (1988) Reduced risk of IDDM among breast-fed children. The Colorado IDDM Registry. Diabetes 37, 1625-1632. 
10. Virtanen SM \& Knip M (2003) Nutritional risk predictors of $\beta$ cell autoimmunity and type 1 diabetes at a young age. Am J Clin Nutr 78, 1053-1067.

11. Barclay AR, Russell RK, Wilson ML, et al. (2009) Systematic review: the role of breastfeeding in the development of pediatric inflammatory bowel disease. J Pediatr 155, 421-426.

12. Pettitt DJ, Forman MR, Hanson RL, et al. (1997) Breastfeeding and incidence of non-insulin-dependent diabetes mellitus in Pima Indians. Lancet 350, 166-168.

13. Owen CG, Martin RM, Whincup PH, et al. (2006) Does breastfeeding influence risk of type 2 diabetes in later life? A quantitative analysis of published evidence. Am J Clin Nutr 84, 1043-1054.

14. Doak C, Heitmann BL, Summerbell C, et al. (2009) Prevention of childhood obesity - what type of evidence should we consider relevant? Obes Rev 10, 350-356.

15. Walker WA (2004) The dynamic effects of breastfeeding on intestinal development and host defense. Adv Exp Med Biol 554, 155-170.

16. Kunz C \& Lönnerdal B (1992) Re-evaluation of the whey protein/casein ratio of human milk. Acta Paediatr 81, $107-112$.

17. Innis SM (1992) Human milk and formula fatty acids. $J$ Pediatr 120, S56-S61.

18. Lönnerdal B (2008) Personalizing nutrient intakes of formula-fed infants: breast milk as a model. Nestle Nutr Workshop Ser Pediatr Program 62, 189-198.

19. Heinig MJ, Nommsen LA, Peerson JM, et al. (1993) Energy and protein intakes of breast-fed and formula-fed infants during the first year of life and their association with growth velocity: the DARLING Study. Am J Clin Nutr 58, $152-161$.

20. Dewey KG, Heinig MJ, Nommsen LA, et al. (1993) Breastfed infants are leaner than formula-fed infants at 1 y of age: the DARLING study. Am J Clin Nutr 57, 140-145.

21. Dewey KG \& Lönnerdal B (1986) Infant self-regulation of breast milk intake. Acta Paediatr Scand 75, 893-898.

22. Hediger ML, Overpeck MD, Ruan WJ, et al. (2000) Early infant feeding and growth status of US-born infants and children aged 4-71 mo: analyses from the third National Health and Nutrition Examination Survey, 1988-1994. Am J Clin Nutr 72, 159-167.

23. Rebhan B, Kohlhuber M, Schwegler U, et al. (2009) Breastfeeding duration and exclusivity associated with infants' health and growth: data from a prospective cohort study in Bavaria, Germany. Acta Paediatr 98, 974-980.

24. Trahair JF \& Sangild PT (1997) Systemic and luminal influences on the perinatal development of the gut. Equine Vet J Suppl 24, 40-50.

25. Thompson FM, Catto-Smith AG, Moore D, et al. (1998) Epithelial growth of the small intestine in human infants. J Pediatr Gastroenterol Nutr 26, 506-512.

26. Yeh KY \& Yeh M (1993) Use of pup in a cup model to study gastrointestinal development: interaction of nutrition and pituitary hormones. J Nutr 123, 378-381.

27. Yeh KY (1983) Small intestine of artificially reared pups: weight gain and changes in alkaline phosphatase, lactase and sucrase activities during development. J Nutr 113, 1489-1495.

28. Yeh KY (1983) Small intestine of artificially reared rat pups: effect of caloric intake and dietary composition on growth and disaccharidase activities. J Nutr 113, 1496-1502.

29. Kanno T, Koyanagi N, Katoku Y, et al. (1997) Simplified preparation of a refined milk formula comparable to rat's milk: influence of the formula on development of the gut and brain in artificially reared rat pups. $J$ Pediatr Gastroenterol Nutr 24, 242-252.

30. Dvorak B, McWilliam DL, Williams CS, et al. (2000) Artificial formula induces precocious maturation of the small intestine of artificially reared suckling rats. J Pediatr Gastroenterol Nutr 31, 162-169.

31. Weaver LT, Landymore-Lim L \& Lucas A (1991) Neonatal gastrointestinal growth and function: are they regulated by composition of feeds? Biol Neonate 59, 336-345.

32. Biernat M, Zabielski R, Yao G, et al. (2001) Effect of formula vs sow's milk feeding on the gut morphology in neonatal piglets. In Digestive Physiology in Pigs, pp. 43-45 [JE Lindberg and B Ogle, editors]. Wallingford, UK: CABI Publishing.

33. Zabielski R, Godlewski MM \& Guilloteau P (2008) Control of development of gastrointestinal system in neonates. J Physiol Pharmacol 59, 35-54.

34. Heitlinger LA, Rossi TM, Lee PC, et al. (1991) Human intestinal disaccharidase activities: correlation with age, biopsies technique, and degree of villus atrophy. $J$ Pediatr Gastroenterol Nutr 12, 204-208.

35. Gupta SK, Chong SK \& Fitzgeral JF (1999) Disaccharidase activities in children: normal values and comparison based on symptoms and histologic changes. $J$ Pediatr Gastroenterol Nutr 28, 246-251.

36. Chowdhury SR, King DE, Willing BP, et al. (2007) Transcriptome profiling of the small intestinal epithelium in germfree versus conventional piglets. BMC Genomics $\mathbf{8}$, 215-231.

37. Backhed F, Ding H, Wang T, et al. (2004) The gut microbiota as an environmental factor that regulates fat storage. Proc Natl Acad Sci U S A 101, 15718-15723.

38. Mountzouris KC, McCartney AL \& Gibson GR (2002) Intestinal microflora of human infants and current trends for its nutritional modulation. Br J Nutr 87, 405-420.

39. Adlerberth I \& Wold AE (2009) Establishment of the gut microbiota in Western infants. Acta Paediatr 98, 229-238.

40. Kleessen B, Bunke H, Tovar K, et al. (1995) Influence of two infant formulas and human milk on the development of the faecal flora in newborn infants. Acta Paediatr 84, 1347-1356.

41. Siigur U, Ormisson A \& Tamm A (1993) Faecal short-chain fatty acids in breast-fed and bottle-fed infants. Acta Paediatr 82, 536-538.

42. Parrett AM \& Edwards CA (1997) In vitro fermentation of carbohydrate by breast fed and formula fed infants. Arch Dis Child 76, 249-253.

43. Nakayama M, Yajima M, Hatano S, et al. (2003) Intestinal adherent bacteria and bacterial translocation in breast-fed and formula-fed rats in relation to susceptibility to infection. Pediatr Res 54, 364-371.

44. Penders J, Stobberingh EE, van den Brandt PA, et al. (2007) The role of the intestinal microbiota in the development of atopic disorders. Allergy 62, 1223-1236.

45. Vaarala O, Atkinson MA \& Neu J (2008) The 'perfect storm' for type 1 diabetes: the complex interplay between intestinal microbiota, gut permeability and mucosal immunity. Diabetologica 57, 2555-2562.

46. Packey CD \& Sartor RB (2009) Commensal bacteria, traditional and opportunistic pathogens, dysbiosis and bacterial killing in inflammatory bowel disease. Curr Opin Neurobiol 22, 292-301.

47. Backhed F (2009) Changes in intestinal microflora in obesity: cause or consequence? J Pediatr Gastroenterol Nutr 48, S56-S57.

48. Söderholm JD, Yates DA, Gareau MG, et al. (2002) Neonatal maternal separation predisposes adult rats to 
colonic barrier dysfunction in response to mild stress. Am J Physiol 283, 1257-1263.

49. Gareau MG, Jury J, Yang PC, et al. (2006) Neonatal maternal separation causes colonic dysfunction in rat pups including impaired host defense. Pediatr Res 59, 83-88.

50. Barreau F, Ferrier L, Fioramonti J, et al. (2004) Neonatal maternal deprivation triggers long-term alterations in colonic epithelial barrier and mucosal immunity in rats. Gut 53, 501-506.

51. Gebbers JO \& Laissue JA (2004) Bacterial translocation in the normal human appendix parallels the development of the local immune system. Ann N Y Acad Sci 1029, 337-343.

52. Urao M, Teitelbaum DH, Drongowski RA, et al. (1996) The association of gut-associtaed lymphoid tissue and bacterial translocation in the newborn rabbit. J Pediatr Surg 31, 1482-1487.

53. Catassi C, Bonucci A, Coppa GV, et al. (1995) Intestinal permeability changes during the first month: effect of natural versus artificial feeding. $J$ Pediatr Gastroenterol Nutr 21, 383-386.

54. Weaver LT, Laker MF, Nelson R, et al. (1987) Milk feeding and changes in intestinal permeability and morphology in the new born. J Pediatr Gastroenterol Nutr 6, 351-358.

55. Udall JN, Colony P, Fritze L, et al. (1981) Development of gastrointestinal mucosal barrier. II. The effect of natural versus artificial feeding on intestinal permeability to macromolecules. Pediatr Res 15, 245-249.

56. Teichberg S, Isolauri E, Wapnir RA, et al. (1990) Development of the neonatal rat small intestinal barrier to nonspecific macromolecular absorption: effect of early weaing to artificial diets. Pediatr Res 28, 31-37.

57. Yajima M, Nakayama M, Hatano S, et al. (2001) Bacterial translocation in neonatal rats: the relation between intestinal flora, translocated bacteria and influence of milk. J Pediatr Gastroenterol Nutr 33, 592-601.

58. Urao M, Moy J, Van Camp J, et al. (1995) Determinant of bacterial translocation in the newborn: small bowel versus large bowel colonization. J Pediatr Surg 30, 831-836.

59. Go LG, Albanese CT, Watkins SC, et al. (1994) Breast milk protects the neonate from bacterial translocation. $J$ Pediatr Surg 29, 1059-1064.

60. Steinwender G, Schimpl G, Sixl B, et al. (1996) Effect of early nutritional derivation and diet on translocation of bacteria from the gastrointestinal tract in the newborn rat. Pediatr Res 39, 415-420.

61. Adrian TE, Soltesz G, MacKenzie IZ, et al. (1995) Gastrointestinal and pancreatic hormones in the human fetus and mother at 18-21 weeks of gestation. Biol Neonate 67, 47-53.

62. Aynsley-Green A, Lucas A \& Bloom SR (1979) The effect of feeds of differing composition on entero-insular hormone secretion in the first hours of life in human neonates. Acta Paediatr Scand 68, 265-270.

63. Lucas A, Boyes S, Bloom SR, et al. (1981) Metabolic and endocrine responses to a milk feed in six-day-old term infants: differences between breast and cow's milk formula feeding. Acta Paediatr Scand 70, 195-200.

64. Salmenpera L, Perheentupa J, Siimes MA, et al. (1988) Effects of feeding regimen on blood glucose levels and plasma concentrations of pancreatic hormones and gut regulatory peptides at 9 months of age: comparison between infants fed with milk formula and infants exclusively breastfed from birth. J Pediatr Gastroenterol Nutr 7, 651-656.

65. Mcclean P \& Weaver LT (1993) Ontogeny of human pancreatic exocrine function. Arch Dis Child 68, 62-65.

66. Cosgrove M, Losty H, Jenkins HR, et al. (1997) Faecal chymotrypsin in small for gestational age infants: effects of nucleotides and breast feeding. Arch Dis Child Fetal Neonatal Ed 76, F201-F202.

67. Le Huërou-Luron I \& Guilloteau P (1999) Effects of age and food on exocrine pancreatic function and some regulatory aspects. In Biology of the Pancreas in Growing Animals, pp. 213-229 [SG Pierzynowsk and R Zabielski, editors]. London: Elsevier.

68. Kalhan SC, D'Angelo LJ, Savin SM, et al. (1979) Glucose production in pregnant women at term gestation. Sources of glucose for human fetus. J Clin Invest 63, 388-394.

69. Aldoretta PW, Carver TD \& Hay WW Jr (1998) Maturation of glucose-stimulated insulin secretion in fetal sheep. Biol Neonate 73, 375-386.

70. Otonkoski T, Andersson S, Knip M, et al. (1988) Maturation of insulin response to glucose during human fetal and neonatal development. Studies with perfusion of pancreatic isletlike cell clusters. Diabetes 37, 286-291.

71. Weinhaus AJ, Tabiin MT, Poronnik P, et al. (2003) Insulin secretagogues, but not glucose, stimulate an increase in $\left[\mathrm{Ca}^{2+}\right] \mathrm{i}$ in the fetal human and porcine $\beta$-cell. J Clin Endocrinol Metab 88, 2753-2759.

72. Srinivasan G, Pildes RS, Cattamanchi G, et al. (1986) Plasma glucose values in normal neonates: a new look. J Pediatr 109, 114-117.

73. Sperling MA, DeLamater PV, Phelps D, et al. (1974) Spontaneous and amino acid-stimulated glucagon secretion in the immediate postnatal period. Relation to glucose and insulin. J Clin Invest 53, 1159-1166.

74. Padbury JF, Roberman B, Oddie TH, et al. (1982) Fetal catecholamine release in response to labor and delivery. Obstet Gynecol 60, 607-611.

75. Kalhan SC, Bier DM, Savin SM, et al. (1980) Estimation of glucose turnover and ${ }^{13} \mathrm{C}$ recycling in the human newborn by simultaneous $\left[1-{ }^{13} \mathrm{C}\right]$ glucose and $\left[6,6-{ }^{2} \mathrm{H}_{2}\right]$ glucose tracers. J Clin Endocrinol Metab 50, 456-460.

76. Hawdon JM, Ward Platt MP \& Aynsley-Green A (1992) Patterns of metabolic adaptation for preterm and term infants in the first neonatal week. Arch Dis Child 67, 357-365.

77. Cornblath M, Hawdon JM, Williams AF, et al. (2000) Controversies regarding definition of neonatal hypoglycemia: suggested operational thresholds. Pediatrics 105, $1141-1145$.

78. Edmond J, Auestad N, Robbins RA, et al. (1985) Ketone body metabolism in the neonate: development and the effect of diet. Fed Proc 44, 2359-2364.

79. Gentz J, Persson B, Kellum M, et al. (1971) Effect of feeding on intravenous glucose tolerance and insulin response in piglets during the first day of life. Life Sci II 10, $137-144$

80. Mendonca AC, Carneiro EM, Bosqueiro JR, et al. (1998) Development of the insulin secretion mechanism in fetal and neonatal rat pancreatic B-cells: response to glucose, $\mathrm{K}^{+}$, theophylline, and carbamylcholine. Braz J Med Biol Res 31, 841-846.

81. Shields BM, Knight B, Shakespeare L, et al. (2006) Determinants of insulin concentrations in healthy 1-week-old babies in the community: applications of a bloodspot assay. Early Hum Dev 82, 143-148.

82. Ginsburg BE, Lindblad BS, Lundsjo A, et al. (1984) Plasma valine and urinary $\mathrm{C}$-peptide in breast-fed and artificially fed infants up to 6 months of age. Acta Paediatr Scand 73, 213-217.

83. Jost R, Maire JC, Maynard F, et al. (1999) Aspects of whey protein usage in infant nutrition, a brief review. Int $J$ Food Sci Technol 34, 533-542. 
84. Macé K, Steenhout P, Klassen P, et al. (2006) Protein quality and quantity in cow's milk-based formula for healthy term infants: past, present and future. In Protein and Energy Requirements in Infancy and Childhood, pp. 189-205 [J Rigo and EE Ziegler, editors]. Vevey: Nestlé Ltd.

85. Colome G, Sierra C, Blasco J, et al. (2007) Intestinal permeability in different feedings in infancy. Acta Paediatr 96, 69-72.

86. Farano S, Boehm G, Garssen J, et al. (2005) Galactooligosaccharides and long-chain fructo-oligosaccharides as prebiotics in infant formulas: a review. Acta Paediatr Suppl 94, 22-26.

87. Barrat E, Michel C, Poupeau G, et al. (2008) Supplementation with galacto-oligosaccharides and inulin increases bacterial translocation in artificially-reared newborn rats. Pediatr Res 64, 34-39.

88. Bovee-Oudenhoven IM, Ten Bruggencate SJ, LettinkWissink ML, et al. (2003) Dietary fructo-oligosaccharides and lactulose inhibit intestinal colonisation but stimulate translocation of salmonella in rats. Gut 52, 1572-1578.

89. Ten Bruggencate SJ, Bovee-Oudenhoven IM, LettinkWissink ML, et al. (2005) Dietary fructooligosaccharides increase intestinal permeability in rats. $J$ Nutr $\mathbf{1 3 5}$, 837-842.

90. Maxson RT, Johnson DD, Jackson RJ, et al. (1996) The protective role of enteral IgA supplementation in neonatal gut-origin sepsis. Ann N Y Acad Sci 778, 405-407.

91. Dickinson EC, Gorga JC, Garrett M, et al. (1998) Immunoglobulin A supplementation abrogates bacterial translocation and preserves the architecture of the intestinal epithelium. Surgery 124, 284-290.

92. Balmer SE, Scott PH \& Wharton BA (1989) Diet and faecal flora in the newborn: lactoferrin. Arch Dis Child 64, $1685-1690$.

93. Roberts AK, Chierici R, Sawatzki G, et al. (1992) Supplementation of an adapted formula with bovine lactoferrin: 1. Effect on the infant faecal flora. Acta Paediatr 81, 119-124.

94. Nichols BL, McKee K, Putman M, et al. (1989) Human lactoferrin supplementation of infant formulas increases thymidine incorporation into the DNA of rat crypt cells. J Pediatr Gastroenterol Nutr 8, 102-109.

95. Hagiwara T, Shinoda I, Fukuwatari Y, et al. (1995) Effects of lactoferrin and its peptides on proliferation of rat intestinal epithelial cell line, IEC-18, in the presence of epidermal growth factor. Biosci Biotechnol Biochem 59, 1875-1881.

96. Buccigrossi V, de Marco G, Bruzzese E, et al. (2007) Lactoferrin induces concentration-dependent functional modulation of intestinal proliferation and differentiation. Pediatr Res 61, 410-414.

97. Berseth CL (1987) Enhancement of intestinal growth in neonatal rats by epidermal growth factor in milk. Am J Physiol 253, G662-G665.

98. Pollack PF, Goda T, Colony PC, et al. (1987) Effects of enterally fed epidermal growth factor on the small and large intestine of the suckling rat. Regul Pept 20, 189-198.
99. Okuyama H, Urao M, Lee D, et al. (1998) The effect of epidermal growth factor on bacterial translocation in newborn rabbits. J Pediatr Surg 33, 225-228.

100. Houle VM, Schroeder EA, Odle J, et al. (1997) Small intestinal disaccharidase activity and ileal villus height are increased in piglets consuming formula containing recombinant human insulin-like growth factor-I. Pediatr Res 42, 78-86.

101. Marion J, Bebin K, Thomas F, et al. (2002) La supplémentation de l'aliment de sevrage en un extrait de colostrum bovin augmente la hauteur des villosités dans le duodénum chez le porcelet sevré (Supplementation of a weaning diet with a bovine colostrum extract increased villi heights in the duodenum of weaned piglets). In Journées de la Recherche Porcine, vol. 34, pp. 103-108 [ITP and INRA, editors]. Paris: ITP.

102. Yu VY (2002) Scientific rationale and benefits of nucleotide supplementation of infant formula. J Pediatr Child Health 38, 543-549.

103. Gil A, Corral E, Martinez-Valverde A, et al. (1986) Effects of the addition of nucleotides to an adapted milk formula on the microbial pattern of feces in at term newborn infants. $J$ Clin Nutr Gastroenterol 1, 127-132.

104. Balmer SE, Hanvey LS \& Wharton BA (1994) Diet and faecal flora in the newborn: nucleotides. Arch Dis Child Fetal Neonatal Ed 70, 137-140.

105. La Leche League International (2003) Breastfeeding statistics. http://www.1lli.org/cbi/bfstats03.html (accessed July 2009).

106. Forste R \& Hoffmann JP (2008) Are US mothers meeting the Healthy People 2010 breastfeeding targets for initiation, duration, and exclusivity? The 2003 and 2004 National Immunization Surveys. J Hum Lact 24, 278-288.

107. Turck D (2005) Breast feeding: health benefits for child and mother. Arch Pediatr 12, Suppl. 3, S145-S165.

108. Lönnerdal B (2003) Nutritional and physiologic significance of human milk proteins. Am J Clin Nutr 77, $1537 \mathrm{~S}-1543 \mathrm{~S}$

109. Hamosh M (1997) Should infant formulas be supplemented with bioactive components and conditionally essential nutrients present in human milk? J Nutr $\mathbf{1 2 7}$ 971S-974S

110. Palou A \& Pico C (2009) Leptin intake during lactation prevents obesity and affects food intake and food preferences in later life. Appetite 52, 249-252.

111. Lien EL (2003) Infant formulas with increased concentrations of $\alpha$-lactalbumin. Am J Clin Nutr 77, $1555 \mathrm{~S}-1558 \mathrm{~S}$.

112. Lonnerdal B (1985) Biochemistry and physiological function of human milk proteins. Am J Clin Nutr $\mathbf{4 2}$ 1299-1317.

113. Bobe G, Lindberg GL, Freeman AE, et al. (2007) Short communication: composition of milk protein and milk fatty acids is stable for cows differing in genetic merit for milk production. J Dairy Sci 90, 3955-3960. 